\title{
Septic arthritis of hip joint and its devastating complications
}

\author{
Kamal Kant Sahu ( , Nicholas Tsitsilianos, Luke Moselle, Ajay Kumar Mishra
}

Department of Internal

Medicine, Saint Vincent Hospital, Worcester, Massachusetts, USA

\section{Correspondence to} Dr Kamal Kant Sahu; drkksahu85@gmail.com

Accepted 26 January 2020

\section{DESCRIPTION}

A 47-year-old man with history of intravenous drug abuse presented to the emergency room complaining of worsening right-sided pelvic swelling and difficulty in walking for the last 2 weeks. Two months before, he had been admitted for methicillin resistant staphylococcus aureus (MRSA) hip septic arthritis which was treated with irrigation and hip joint debridement along with intravenous vancomycin (figure 1A). Unfortunately, he only completed 2 weeks of antibiotics as he left rehabilitation centre against medical advice.

At this his current admission, physical examination showed soft tissue oedema (figure 1B) around the right hip. Compared with previous imaging, the latest radiograph (figure 2A) and CT scan (figure 2B) showed significant progression of hip joint destruction with partial femoral head resorption. Blood work demonstrated leucocytosis $\left(14.1 \times 10^{9} / \mathrm{L}\right)$ as well as high $\mathrm{C}$ reactive protein (CRP) $(11 \mathrm{mg} / \mathrm{dL})$ and erythrocyte sedimentation rate (ESR) $(55 \mathrm{~mm} /$ hour). His other blood results include negative serological studies for Hepatitis B virus (HBV), Hepatitis C virus (HCV) and syphilis. Unfortunately, HIV was not researched in this patient. Joint aspirate was turbid in appearance, with an elevated white blood cell (WBC) count $\left(130.6 \times 10^{9} / \mathrm{L}\right)$ and $93 \%$ neutrophils. Both blood and joint aspiration cultures grew MRSA, and the patient was prescribed with intravenous vancomycin for 6 weeks. Also, considering the extensive damage of hip joint and underlying osteomyelitis proximal femur resection, debridement and irrigation was done. Superficial abscess was drained and the collapsed, necrosed bone was removed. $\mathrm{He}$ was discharged for ambulatory follow-up
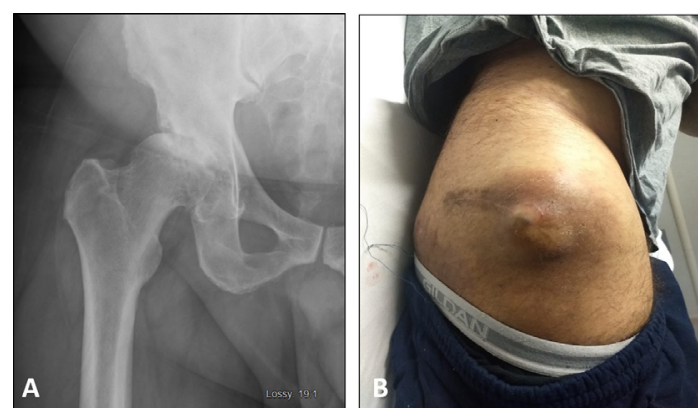

Figure 1 (A). Hip X-ray during previous visit showing evidence of degenerative changes and loss of femoral head contours. (B) Clinical image of right pelvis showing massive swelling which was tender and warm on palpation.
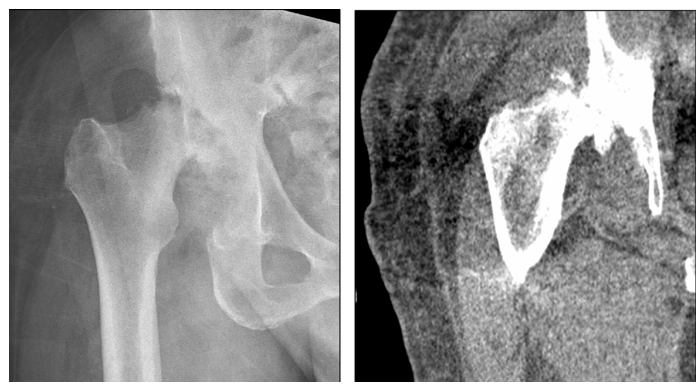

Figure 2 (A) Repeat hip X-ray during current admission. (B) CT confirmed progressive erosive changes involving the right femoral head, right acetabulum and septic arthritis.

while maintaining long-term intravenous vancomycin for a total of 6 weeks, physical therapy, pain management medication and considering a possible hip replacement in the future after infection eradication.

Suspected cases of bacterial arthritis should be evaluated promptly. ${ }^{1}$ Immunocompromised state, diabetes, previous surgical procedures or intravenous drug abuse are considered important risk factors for atypical infections. ${ }^{2}$ Our case demonstrates the importance of compliance to antibiotics which could have averted the complications of hip joint destruction. Staphylococcus aureus is the most commonly identified pathogen as was in our case. ${ }^{3}$ In sexually active individuals, work up for Neisseria gonorrhoeae should also be done.

Initial work up of suspected septic arthritis should include joint aspiration. MRI is highly sensitive for the early detection of joint fluid. However, ultrasonography (USG) is readily available, cost-effective and has a high negative predictive value. USG-guided aspiration could also help to decompress the joint apart from providing synovial fluid samples. ${ }^{4}$

With regard to empirical therapy, initial choice of antibiotics should be aimed at covering the most likely pathogens. Synovial fluid culture helps in guiding targeted further treatment. Duration of

\section{Learning points}

- Septic hip is a rare condition and it can be difficult to treat if not managed properly.

- Compliance and adherence to antibiotics is the backbone to prevent progression of septic arthritis to joint destruction and osteonecrosis. 
therapy in such cases is variable and depends on patient clinical response and inflammatory markers serial measurements. ${ }^{5}$

Contributors KKS wrote the manuscript and reviewed literature. NT reviewed manuscript writing. LM performed manuscript writing and management of the case. AM reviewed literature management.

Funding The authors have not declared a specific grant for this research from any funding agency in the public, commercial or not-for-profit sectors.

Competing interests None declared.

Patient consent for publication Obtained.

Provenance and peer review Not commissioned; externally peer reviewed.
ORCID iD

Kamal Kant Sahu http://orcid.org/0000-0002-0382-6882

\section{REFERENCES}

1 Lee Y-K, Won S, Yeom J, et al. Concomitant septic arthritis of the hip in patients with osteonecrosis of the femoral head. Surg Technol Int 2019;35:402-5.

2 Lal A, Mishra AK, Sahu KK, et al. Tuberculous cold abscess eroding iliac bone. Revista Española de Patología 2020:53:71-2.

3 Herman G, Zehr S. Osteomyelitis of the Glenohumeral joint. J Orthop Sports Phys Ther 2019:49:865.

4 Sahu KK, Mishra AK, Nandagopal D. Pseudogout: a rare cause of joint swelling during postoperative period. BMJ Case Rep 2019;12:pii: e230089.

5 Sahu KK, Chastain I. A rare case of Holocord spinal epidural abscess. QJM 2019:pii: hcz291.

Copyright 2020 BMJ Publishing Group. All rights reserved. For permission to reuse any of this content visit

https://www.bmj.com/company/products-services/rights-and-licensing/permissions/

BMJ Case Report Fellows may re-use this article for personal use and teaching without any further permission.

Become a Fellow of BMJ Case Reports today and you can:

- Submit as many cases as you like

- Enjoy fast sympathetic peer review and rapid publication of accepted articles

- Access all the published articles

Re-use any of the published material for personal use and teaching without further permission

Customer Service

If you have any further queries about your subscription, please contact our customer services team on +44 (0) 2071111105 or via email at support@bmj.com.

Visit casereports.bmj.com for more articles like this and to become a Fellow 